\title{
A PARADIGM SHIFT IN PRE-THEORETICAL DELIBERATIONS ON CRIME WITHIN SPIRITUAL EXISTENTIALISM
}

\author{
J R Roelofse
}

\section{University of Limpopo}

\begin{abstract}
Explanations on the origins of life, spiritual possession and death after life cannot be explained from a naturalistic, positivistic methodological view point simply because scientists have not ventured deep enough to develop measuring instruments for these phenomena. This inadequacy in positivism has led to the exclusion of theoretical explanations of crime and desistance as a result of spirituality. The anomaly can be discharged, had it not been that a bias has developed against spiritual phenomena which is substantiated in this article. In a liberal world, emphasising freedom of conscience and speech, this is a contradiction worthy of enquiry. Our existential world has for ages been affected by behaviour, claimed to be influenced by the supernatural. The question is whether criminologists can ignore phenomena such as spiritual possession claimed by especially Africans, aboriginal peoples and some religions? Many perpetrators, by their own testimonies, as indicated in the article, have been motivated by spiritual phenomena in the perpetration of crime. It is necessary to indicate that the article does not favour a purely spiritual (or religious) approach to crime but calls for an epistemological assumption within Criminology that encourages philosophical debates and theory development, giving consideration to spirituality. This article argues for a pre-theoretical debate in criminological philosophy ${ }^{1}$ and to develop our research into a phenomenological capacity to deal with metaphysical issues.
\end{abstract}


A paradigm shift in pre-theoretical deliberations on crime within spiritual existentialism

Keywords: Philosophy, metaphysics, phenomenology, spiritual possession, occult, Satanism, crime

\section{INTRODUCTION}

Criminological philosophy attempts to introduce philosophy of crime and existential epistemology, as a foundation for research, from which theory can be developed. Philosophy is a way of using critical, logical, and systematic thinking to examine deeply held beliefs or social practices, a preamble to theory (Warren, 1989). It is not meant to replace theory but precedes theory. The philosophical premises should be the constructs and ideas from which grand theoretical perspectives can be deduced. As Himes and Schulenberg (2013:1) put it, "Philosophy and theory are perpetually linked; philosophy influences how one sees the world, theory shapes how one intentionally interacts with that world". This means that our philosophical foundation will determine how we see the world and that will determine how we interact with our surroundings.

There are entrenched paradigms that need to be challenged which will clearly indicate the necessity to review our philosophical approach to criminology. Let us just for a moment doubt science and challenge its dogma. What if science is not able to measure a dimension of life due to its abstract dimensions, then ignores it and teaches people to take this dimension into privacy, insisting that this dimension should not also assert itself in the public domain? What if people intuitively know that there is a spiritual world and are bombarded by scientific dogma to ignore it? Explanations on the origins of life, spiritual possession and death after life cannot be explained from a positivistic methodological view point simply because scientists have not extensively explored methods to develop measuring instruments for these phenomena. If individuals believe (and experience) sacred or evil things and are then 
"scientifically" informed that they are "hallucinating" anxiety and depression may follow. Scientists are not comfortable when confronted by mysticism, metaphysical tendencies and religion. Despite this stance of scientists (physical), to not engage in matters that cannot be scientifically measured, millions of lives around the globe are affected by "super-natural phenomena." Okawa (2014), within an African orientation, puts it this way:

Spiritual possession can be the cause of illnesses, mental disorders or even crimes, but this phenomenon is not being treated appropriately since modern medicine and science do not recognize the existence of spiritual possession. Fact is, though, the phenomenon of spiritual possession is a common occurrence.

This statement clearly indicates that the belief that a human being can be possessed by an evil spirit is recognised by some cultures and writers. It is the role of philosophy to argue and explain such phenomena. The article is not an attempt -, as Fields (1991:167) puts it, to reduce, "...the causes of a problem [and] its complexities to simple demons". The aim of this article is rather to make a call for the introduction of criminological philosophy in an attempt to introduce metaphysical and other phenomena, into a criminological perspective and to challenge researchers (particularly with an ethno-criminological perspective) to eventually develop theory within a metaphysical framework. It is not necessary to prove the existence of supernatural phenomena and things like demons and angels but rather to develop research that can develop an understanding of how these phenomena (true or not) affect behaviour. 
A paradigm shift in pre-theoretical deliberations on crime within spiritual existentialism

\section{BACKGROUND}

Landauer and Rowlands (2001) as well as Vlach (2002) deal with the five branches of philosophy, namely metaphysics (study of existence or what is out there), epistemology (study of knowledge - how do I get to know about what is out there); ethics (relating to what should one do, based on the former two questions); politics (study of force and what actions are permissible); and aesthetics (art and what can be known about life). There is clearly a hierarchical construction in these subfields of philosophy. As Landauer and Rowlands (2001:1) put it:

At the root is Metaphysics, the study of existence and the nature of existence. Closely related is Epistemology, the study of knowledge and how we know about reality and existence. Dependent on Epistemology is Ethics, the study of how man should act. Ethics is dependent on Epistemology because it is impossible to make choices without knowledge.

From this perspective the argument is put that we cannot truly proceed with knowledge if the foundation of metaphysics is not understood and informs the other four subfields. Landauer and Rowlands (2001:1) argue, that the accuracy with which the metaphysical worldview is interpreted determines the degree to which we comprehend the world. "Without this firm foundation, all knowledge becomes suspect. Any flaw in our view of reality will make it more difficult to live".

This statement drives the whole argument unfolding in this article. What if we have built on an exclusive philosophy that led to an exclusive epistemology, in particular, ignoring phenomena labelled as "supernatural"? The branch of philosophy, called "metaphysics", meaning "beyond the physical", deals with these matters. It focuses on the existence of God, 
the soul, and life after death. However, the metaphysical construction is completely absent in criminological theory (apart from the religious school that has been abandoned decades ago). A scientific epistemology which excludes debates on these issues may create an exclusive worldview and would be responsible for a prohibition of existential experiences of a very large portion of the world's population. This would mean that people are scientifically alienated from their supernatural experiences of their existential world. Why do we not at least attempt to develop research questions that guide research to explore the metaphysical as part of constructing, for criminology, a worldview that explains matters from the lived experiences of people? Scientifically designed research to explore firmly held beliefs is not supposed to be marginalised but encouraged as phenomenological enquiry.

One paradigm that seems to hold the position of a privileged position is evolution. It is an example where opposing world views are simply excluded from school curricula so it becomes a singular theory without any challenge within the liberal arts curriculum. Is this science or scientism? For instance the Supreme Court in America, has rejected the appeal of an Ohio public school science teacher who was fired for promoting the theory of creationism and refusing to remove religious materials from his classroom. The court ruled that the school district "... had grounds to fire John Freshwater in 2011 for insubordination for keeping religious books and a poster of a praying president" (Smith \& Welsh, 2013). The question is, would one succeed if a similar complaint against teaching evolution and displaying pictures of Darwin is filed? It is clear that our secular worldview has become intolerant of religious views. As Hallett (1999:1), referring to an article on religious values and criminal justice for a Christian forum, puts it, "... it offers me the freedom to speak my mind about an issue not 
A paradigm shift in pre-theoretical deliberations on crime within spiritual existentialism

entirely welcome in my usual forum, that of the secular State university". This is part of the problem in current social and natural sciences that precludes all relevance of religion in debates. This stance is opposed by van Binsbergen (2001:1) an academic and philosopher, who became a Southern African diviner-priest (isangoma). He states that:

$\ldots$ at the existential level one can only practice sangomahood, and bestow its spiritual and therapeutic benefits onto others as clients and adepts, if and when these beliefs take on a considerable measure of validity, not to say absolute validity, at least within the specific ritual situation within which these practices are engaged in.

In an interview with an isangoma, Fonteleve (2010:1) reports that the respondent said that a isangoma is called by ancestors "... and works mainly with ancestral spirits". In some instances strong muti (medicine) is used, which consists of plants, herbs and animal and human parts. This point will be addressed again later.

The context of the isangoma is spiritual. The context of religion is spiritual. This applies to all religions including those such as occultism and Satanism. In the context of this article it is not postulated that crime can simply be explained by malevolent spiritual possession and desistence by benevolent spiritual possession. The question is rather how a particular worldview and spiritual connection motivate behaviour, inter alia, also criminal behaviour or desistance? The struggle between good and evil are aptly captured by Krishnananda (2015) when he opines that man is a dualistic being, having both good and evil in us. He asserts that there is a continuous tussle between malevolent and benevolent forces within our being. Christianity also refers to a condition of being in this tussle between good and evil. The Holy Spirit is present in the 
believer, but with the baptism in the Holy Spirit (Kostenberger, 1997:229) the believers are endowed with certain gifts such as healing and prophecy.

Okawa (2014) and Binsbergen (2001) indicate that spiritual forces are acknowledged in African mythology. Beaulieu (2011: 28) quotes Duran who asserts that, "Lack of understanding of the Native epistemological root metaphor (ways of being in the world including psychological and spiritual world) continue to hinder our progression." In the article on muti murder ${ }^{2}$ the author deals with aspects of mythology in Africa as a driving force for muti (medicine) murders. This evil practice of removing body parts from a victim is driven by the belief that life energy can be obtained through the body parts of a victim and therefore the parts are preferably removed while the victim is alive. This energy that is sought after is transcendent. The motive for killing is thus to obtain supernatural power by the harvesting of life energy through body organs. In the same context, police experts presented evidence, to the Farlam Commission, investigating the shooting of 34 mine workers at a platinum mine near Marikana in the Northwest province by the South African Police Service, (SAPA) that the striking workers applied muti to make them invisible and/or immune to bullets (Maromo, 2013). The muti, according to evidence was harvested from a security guard and a police officer, killed two days before the confrontation with the police. SAPA (2014:1) reports that a witness, simply known as Mr. X, stated during cross examination, "We killed them at the bus stop. We burnt one in the car and we took pieces of flesh from the other one. That would make our muti

\footnotetext{
2 See Roelofse, CJ. (2014) Ritual and muti murders amongst the vha-Venda people of South Africa: An ethno-criminological assessment of the phenomenon and development of a new typology. Acta Criminologica (Special edition: Research and application in Criminology \& Criminal Justice/1/2014
} 
A paradigm shift in pre-theoretical deliberations on crime within spiritual existentialism

strong, so that we go forward when we attack". The ash is normally mixed with other ingredients such as herbs and one of the ways to apply muti is to make incisions in the body and rub it in so that it is absorbed. Part of it may be ashes (in this instance retrieved from the remains of the body in the car). In the interview conducted by Fonteleve (2010:1) cited above, the respondent claimed that a baby in the bloodline, destined to become an sangoma, will be induced with muti through incisions in the body. The practice of administering muti by inducing it into the recipients blood is thus a standard practice in the culture of the "informed".

It is evident from the above discussion that spirituality is not only a religious tenet but it is the subject of reflection, publication and inspiration for daily living in the lives of many people on the planet including those who commit crime. As Ovens and Prinsloo (2010: 4) opine, African theories and paradigms should furthermore not merely be applied to explain crime and causality, but also to direct researchers and practitioners in explaining criminal behaviour..." The African context of this point is clear, yet religions such as Voodoo, Santeria and Wicca are exports from Africa and Europe, practiced in America, the Caribbean and Europe. A wider application of an epistemology that transcends cultural limitations and geographical boundaries is contemplated. The metaphysical foundation of a religion and /or culture is the motivational dimension of belief and eventually, behaviour. Groff and Smoker (1996) write that when religious beliefs become rigid and dogmatic, acquiring the dimension of the only truth while other religions and non-believers, or even variations of the same religion are rejected, it leads to "fundamentalism" or "fanaticism" or "extremism". Horrific crimes and even genocide has been committed by extremists in the past and are still being perpetrated in our post-modern society. The conflict in Northern Ireland 
between Catholics and Protestants and the beheadings by some elements in ISIS (Islamic State of Iraq and Syria) come to mind. Criminological philosophy seems to be an appropriate means of engaging these problems and endeavouring to develop explanations and control measures.

Having indicated the hierarchy in philosophy as unpacked by Landauer and Rowlands (2001) as well as Vlach (2002) and the impact of metaphysics, it is necessary to discuss the branches of philosophy in the context of this article.

\section{Metaphysics}

As our worldview influences our epistemology, criminologists should not fall into the trap of exclusive scientism. Braterman (2005:1), concerning the supernatural, boldly states that "I argue that this view is misguided and damaging. We have not precluded supernatural claims from discussion. On the contrary, we have investigated them and found them wanting..." This is scientism at its most judgmental level. If one cannot observe deceitful thoughts, can we argue that they do not occur because they are unobservable? Should we not rely on informants' experiences of spiritual things and how it affects them? Similarly, criminologists should not reject metaphysical perspectives but study them from the lived experiences of informants. In an African context, Momoh (1989), argues for a philosophical worldview based on a metaphysics. This is supported by Agidigbi (2001) who opines that African philosophy largely proceeds from metaphysical principles and this is the foundation for resolving religious, social and political issues. This metaphysical worldview creates a moral perspective that Izibili (2005:1) describes as based on the notion that God is concerned about morality. Good and evil are concepts based on a worldview of spirituality but are then socially defined. He proceeds to argue that: 
A paradigm shift in pre-theoretical deliberations on crime within spiritual existentialism

- God cannot be indifferent to human welfare because he is a good God;

- Because he cannot be indifferent to human welfare, He cannot also be indifferent to morality; and

- Therefore, he (God) ensures justice by rewarding the virtuous and punishing evil doers through the agency of the gods who serve Him (Izibili, 2005:12).

Good and evil are concepts that are found in virtually all cultures and religions. From a criminological perspective it is necessary to single out the good for purposes of desistence and the evil (when contravening law). The dilemma of ambiguity is a challenge for our discipline. Worldviews that create social and legal conflict may lead to crime. Within the African context muti and ritual murders clearly accentuate the ambiguity that lies within the concept of perceived good and evil. It is the moral evaluation that the community attaches to an event. If for example someone's house burns down: have they received just deserts or is their suffering unjustified? There is in fact, in African society ambivalence based on moral legitimacy. The same ambivalence is also prevalent in Haitian Voodoo. Among some African peoples "witchcraft" is intrinsically neither morally good nor bad, while the supernatural activities of witches are judged on their perceived effects and divided into good, protective and bad or destructive witchcraft (Eb.com.blackhistory, 2008:1; Petrus, 2010; Roelofse, 2014). African spirituality is therefore a fight between good and evil. That which is harmful to a community is evil and must be resisted. The concepts of good and evil, traverse cultures and religions and are not confined to African philosophy.

Malevolent spirituality is evident from the life of Charles Manson. According to Kennedy (2006: 19), Manson established 
himself as a leader. He started to draw a group of followers who were primarily well educated, young women with middleclass upbringings. These attractive females suffered from deep-rooted psychological problems and took rebellious stances against their parents and the consumerist economy. They all used illicit drugs as part of their counter-culture lifestyle (Kennedy, 2006). Their lives being influenced by drugs and the occult, lead to crime and eventually the murder of Sharon Tate. Having discussed the metaphysical component within a criminological context, the logical development is to engage epistemology.

\section{Epistemology}

Epistemology and ontology are the fundamental views, theory of knowledge and view of reality that will shape our theoretical perspectives and methodology (Raddon, 2015:4). Mankind are all products of a developing epistemology that shapes doctrine and it is prudent to reflect to what extent our beliefs have influenced our epistemology. The venture of this article is to try and stimulate debate about metaphysics, epistemology and praxis. How does different beliefs affect and stimulate criminal behaviour and how can philosophical and theoretical deliberations explain these phenomena?

Some paradigmatic changes have taken place in the world. The advancement of science has brought major progress in all domains of our lives. The advance of medical science, aviation and computer science to mention just a few, have changed our world. However, natural scientists have reserved the space as the sole guardians of all truth. The dogmatic stance on science is what has been coined "scientism".

Scientism is the worldview held by a majority of people in the western world that claims that all that 'is' and all that 'can be known' is verifiable or falsifiable through the scientific method, 
A paradigm shift in pre-theoretical deliberations on crime within spiritual existentialism

and that which cannot be so measured is simply opinion, belief, or fantasy. It cannot be known and sensibly talked about and hence should be relegated to the private sphere (Beiden, 2007:1).

As indicated earlier, scientists are sceptic about the existence of a spiritual world. This is an exclusive approach where only science is recognised as having access to truth. Whatever falls outside the scientism approach is superstition, conjecture and fantasy. This is vividly demonstrated in a quote from Braterman (2014: 7):

"I have no need of that hypothesis." So, according to legend, said the great astronomer and mathematician PiereSimon, marquis de Laplace, when asked by Napoleon why he had not mentioned God in his book. If so, Laplace was not referring to the hypothesis that God exists, but to the much more interesting hypothesis that He intervenes in the material world. And Laplace's point was not, fundamentally, philosophical or theological, but scientific.

This argument states that there is only room for science and science takes precedence over religion. Logic necessitates that reasoning is based on verifiable data according to positivistic empiricism (Mastin, 2008). Logical positivism, or logical empiricism, as a philosophical movement, originated in the early twentieth century in Vienna. and holds the view “... that scientific knowledge is the only kind of factual knowledge and that all traditional metaphysical doctrines are to be rejected as meaningless" (Encyclopaedia Britannica, 2015:1). Mastin (2008) proceeds to explain that a standard scientific language is being developed into which all knowledge should be coded "... and the associated ongoing project of "rational reconstruction", in which ordinary-language concepts were gradually to be replaced by more precise equivalents in that standard language". 
According to Younkins (2000), Kant argued that reality is dependent on the cognitive functioning of the human mind in total. "Society sets the norms of truth and falsity and right and wrong". (Ibid., p.1). This implies that there exists a moral mobility that is dependent on dictates of a changing social context. This is the crux of Kant's social primacy of consciousness theory in metaphysics.

Man's ideas are essentially a collective delusion from which no person has the power to escape. If a man sees things differently from the majority, then he must be mistaken due to some defect in his own information processing mechanism. Since and because of Kant, "objectivity" is generally thought to mean collective subjectivism. Truth, to the extent that it can be known in the phenomenal world, is to be determined by means of public polls (Younkins 2000:1). The paradox of a majoritarian subjectivism, replacing "objectivity" functions in a Delphi-rehearsal until consensus emerges. Hence individuality is usurped by mass conversion to a particular doctrine and new language (Mastin 2008). Thus there is a universal conception by which individualism becomes alien. The standard language is the language of the prevailing dogma of the relative worldview. The logical flaw in this argument lies within the historical concept of our world and the fact that standard language is removed from history. If we do not exactly, scientifically know history (in this case of the origin of the cosmos and life) how can we base science on inaccurate historical propositions?

In regression, knowledge is based on a regression foundation where premise 1 is based on 2 and 2 on 3 and so ad infinitum. Rational empiricism takes a gigantic leap into the foundational premise (of the origin of life and species) which is not knowable outside of revelation. To construct a theory such as 
A paradigm shift in pre-theoretical deliberations on crime within spiritual existentialism

evolution requires not only regression analyses but also progressive analyses of which one branch should be futuristic evolution and questions such as what is man evolving to become or at least provide logical explanations why evolution has slowed down or even came to a halt? To build science, opposing views cannot simply be brushed aside and then change the scientific language to suite scientism (Mastin, 2008). This makes the tools of research the judges of knowledge and not the data extracted from the phenomena being researched. Excluding everything that scientism does not approve of implies selective epistemology.

Human behaviour is not always rational but can be erratic at times and as demonstrated earlier, influenced by metaphysical tendencies. The motivation of this article is to call for a pre-theoretical paradigm, searching for explanations of behaviour that involves criminality motivated by metaphysicallydriven pre-dispositions. Criminological philosophy should be an approach in criminology that rely on qualitative methodology to do research on how particular worldviews, acknowledging the spirit world, influence behaviour. Such questions as how does a secular or spiritual worldview act as desisting or precipitating motivational dimensions in crime, should be philosophically debated and give direction to research in order to formulate theory. Furthermore, do different religions have a different impact on their followers and how does this effect desistence or predisposition? It is not an argument simply based on a spiritual paradigm but an attempt to uncover the lived experiences of people who claim to have been influenced by a spiritual worldview. Through using a phenomenological approach, and by making enquiry into the lived experiences of people, philosophical and theoretical perspectives can be developed. It should however be said that courts recognise the spirit world, calling on those who testify to 
swear by God that they will speak "the truth and nothing but the truth, so help me God". The preamble to the South African Constitution, Act 108 of 1996 asks God to bless Africa. While courts are considering God and religion it is interesting to note Perlmutter's (2013) opinion. As an expert witness in occult crimes mentioned earlier, she calls for a suspension of Western values. It is an interesting stance as the original western construction of the metaphysical world was based on biblical principles. These have already been suspended. Her call is now to suspend the current secular paradigm for a new spiritual one in which occult practices can be explained. This presents the crime precipitating part of mysticism while this article also calls for the malevolent and desisting part of spirituality and religion. The influence of a particular worldview is interestingly enough evident from court proceedings in the UK.

A judgment in the UK has taken religious education into account in sentencing. Zaimov (2015:1) reported on a case where an 18 year old boy admitted that he had sex with an under-aged girl but was ignorant of the fact that his action constituted rape "... because he was raised with a Muslim education and was not aware of the law". Spencer (2013:1) reports that judge Michael Stokes did not impose a jail sentence on the accused who apparently was taught in an Islamic faith school that women were worthless. The question here is to what extent natural law moderates this opinion in a justice perspective or whether a worldview takes precedents in the penelogical part of sentencing? In this case it clearly did. This is certainly an opportunity for criminological philosophy to make a contribution. This logically leads to ethical considerations 
A paradigm shift in pre-theoretical deliberations on crime within spiritual existentialism

\section{Ethics}

Ethics, the study of how man should act, is also informed by our worldview as interpreted through our epistemological approach. Humanists believe some things are right for some people and some situations, that may be "wrong" for other people and other situations. Particular examples are abortion and euthanasia. The secular worldview argues that everything depends on the situation and values, morals, and ethics are determined by each person for him or herself. Therefore, to tell someone else that their behaviour is "wrong" or "sinful" is considered to be intolerant. "Intolerance" (defined this way) is not tolerated (Hall, 2005:1 -30). Knowledge, derived from a particular worldview, therefor directs epistemology and in turn it influences ethics.

Philosophers deal with justifications mainly through a priori and a posteriori knowledge. Philosophy states that any given proposition is knowable a priori if knowledge is obtained independent of experience other than the experience of learning the language in which it is expressed. A proposition that is knowable a posteriori is known based on experience (Bhaer, nd:1). If a religion, folklore or culture teaches a metaphysical perspective on life as a priori knowledge and a believer or adherent to a particular worldview experiences an event that is super-natural (a posteriori) how does our ethics engage this? The question is whether knowledge can also develop in a metaphysical way? Transcendentally, there is another form of knowledge, namely revelation, claimed by religious people (a metaphysical way of knowing). These are the questions that criminological philosophy should endeavour to explain as far as such experiences may lead to criminal activity or desistance. 


\section{Revelation}

Revelation is not conditional. It is not based on a priori and a posteriori knowledge. Revelation is a way of knowing outside the realms described by current philosophical deliberations. This is a particular spiritual way of knowing. Author C. S. Lewis was an atheist for the first three decades of his life. Then, after much soul searching, he concluded that God exists. This was not, however, the end of his religious transformation. On September 28, 1931, at age 33, he got into the sidecar of his brother's motorcycle to travel to Whipsnade Zoo near London. "When we set out," he says, "I did not believe that Jesus Christ is the son of God, and when we reached the zoo I did. Yet I had not exactly spent the journey in thought. Nor in great emotion. . . . It was more like when a man, after a long sleep, still lying motionless in bed, becomes aware that he is now awake." (Connor, 2015:1). The apostle Paul ${ }^{3}$ wrote in Galatians 2:21, "I went there because God revealed to me that I should go". To evaluate such a statement it is necessary to look at faith. Swindal (n.d. 1) indicates that "[r]eligious faith involves a belief that makes some kind of either an implicit or explicit reference to a transcendent source. The basis for a person's faith usually is understood to come from the authority of revelation". Revelation can either be from a direct source, or indirect, as a result from a testimony by another person. He continues to argue that, "The religious beliefs that are the objects of faith can thus be divided into those what are in fact strictly demonstrable (scienta) and those that inform a believer's virtuous practices (sapientia)". Revelation is not dependent on effort but is a consequence of a priori knowledge that becomes a spiritual revelation of matters that are transcendental in nature. This is dependent on a belief that man

${ }^{3}$ New Living Translation 
A paradigm shift in pre-theoretical deliberations on crime within spiritual existentialism

is a spirit being as well and that recognising the spirit world man can receive revelation. By not recognising the spirit world and by excluding the possibility that man can have revelation of this world and interact with it, revelation is excluded as a form of knowing things. This is the shortcoming in positivistic epistemology. By not engaging in a phenomenon that is not measurable, it is already labelled as unscientific. This is why Ellerby (2006) calls for an Integrated Indigenous Phenomenology. This is discussed later in the article. Phenomena that cannot be explained through existing empiricism abound and are in need of investigation. This particularly interests the author in as far crime forms part of such phenomena.

\section{OCCULT AND CRIME}

The recognition of harmful practices and crime stemming from Satanism and some occult practices can be substantiated by the fact that police organisations in some countries have established specialised units to deal with crimes emanating from such practices. The national commander of the unit in South Africa during a media briefing said. "Drug abuse is the common denominator in all levels of satanism... it is the primary source of mind-altering experiences for the satanists, thereby giving them a false sense of power and spiritual potency". (Lamprecht, 2014:1). In the same statement is was revealed that the Gauteng Provincial Harmful and Religious Practise Unit were currently investigating 48 dockets and have interviewed 452 people. In a case in Soweto, two teenagers who committed murder admitted that they got interested in the occult and starting worshipping Satan and performed rituals such as lighting candles and drinking blood. They wanted power and wealth (Jordaan, 2015:1). Accused number one indicated that he became aware of Satanism in 2010 at the age of 12 . He was listening to a lot of Rap music and discovered that rappers were talking about Satanism. He 
also discovered that certain rappers and pop stars in the United States were worshipping Satan which led to their success. Through the internet he started doing his own research about Satanism, as he desired to be successful in life. Accused number two said, in connection with the murder that he felt as if he was burning up, he was then transported to a desert where it was extremely hot. He then started digging for water, he dug deeper for water as he was about to drink the water he then came back to the scene. That is when he realised that his act of digging in the desert, he was actually stabbing one of the deceased. After that he gave the knife to the other child offender who said that he heard the demons instructing him to destroy the deceased who refused to carry out the ritual (Case No: PLI 137/2014). The statement seems to indicate, that at least temporarily, the perpetrator was under the control of another force. This murder occurred in Soweto in South Africa. In another part of the country satanistic motivated behaviour was experienced

In the Free State, in central South Africa, Fouche, (2012:1) reports that a trauma therapist in the capital city of the province, Bloemfontein, remarked on a group, known as 666s, that oversees a number of other gangs such as the Born to Kill, Natural Born Killers and International Junior Portuguese). "Members of the 666 gangs are typically involved in crimes such as armed robberies and trade in human body parts." What has been witnessed in the Free State, is the outcome of a migration from West Africa. Much as Voodoo and Santeria are considered as Afro-Caribbean religions, they hail from West Africa and

...originated in the $18^{\text {th }}$ and $19^{\text {th }}$ centuries during African slave trading when owners imposed Catholicism on their slaves and forbade traditional religious practices. In an at- 
A paradigm shift in pre-theoretical deliberations on crime within spiritual existentialism

tempt to maintain their cultural and religious beliefs, Africans disguised their religion by assigning each of their gods the image of a Catholic saint... (Perlmutter, 2013:4).

This is confirmed by Valentine, (2011:1) who writes that slaves in Louisiana (USA) developed a syncretic religion by amalgamating Catholicism with ancient "Vdoun" (Voodoo) that developed in West Africa.

The first base of settlement for the 666 migrants was in Lesotho and then from there they spread into the eastern Free State and then further throughout the province. De Beer (2012:1) writes that:

At this point groups were loosely structured and more focussed [sic] on ritual magic, blood sacrifices, the drinking of blood and worshipping Satan as deity. As these devil worshipping cults grew over a period of 15 years, they spread throughout the Free State province, especially in the rural areas. They became known as the 666's.

Further reports of occult activity emanate from reports about a new phenomenon that has gripped teenagers around the globe, the so-called charlie-charlie "game". The "game" is infesting schools in South Africa. This involves two pencils placed in the form of an " $X$ " one over the other, and the words "yes' and "no' written on a paper and asking Charlie questions. The pencils then move by some force without any of the participants touching it. Erasmus (2015: 6) reports that children in a school in Limpopo showed erratic behaviour after being exposed to the game. Eye witnesses stated that when a teacher started to pray the pencil stopped moving. These are reports of those who witnessed the events. Pieterse and Umraw (2015:1) report form Pietermaritzburg that they spoke to top learners in a number of private and public schools about the phenomenon. They also describe the game as be- 
ing played on a piece of paper in a similar fashion as described above. It seems to be a different version of "... the older Glassy Glassy game and is said to summon a demon known in Mexican folklore as "Carlitos", who moves the pencils to answer questions posed to him". According to the writers a learner said that he played it together with some friends out of pure curiosity, ...but ... When the pencil moved after we asked Charlie if he was in the room, we all got up and ran," (Pieterse and Umraw (2015:1). These reports of something out of the ordinary based on reports of those who participated or observed the "game" are worthy of inquiry. This cannot simply be brushed aside as irrational. We should clearly heed the calls from researchers like Perlmutter (2013); Ellerby 2013) to shun our Western epistemological ideas and look at ways of doing research on the supernatural Integrated Indigenous Phenomenology. The only proviso the author has is that spiritual phenomena cannot be confined to Africa. The epistemology advocated by Ellerby (2006) should rather make room for a metaphysical phenomenology.

\section{CRIMINOLOGICAL PHILOSOPHY AND CRIME}

Volumes have been written about crime, its possible causes and solutions. This article argues for a more tolerant epistemology that also considers alternatives to the current secular view and allows research into phenomena in a way that is not exclusivist. Having indicated that criminologists should take cognisance of the fact that some perpetrators indicate contact with the spiritual world, the challenge to researchers is to carry out research based on alternative worldviews (meaning other than secular) and to look at spiritual possession by forces reported to be malevolent or benevolent as precipitators or desisting forces. The influence of occult associations, black magic and harmful religious practices should be thoroughly researched in their relationships/associations with 
A paradigm shift in pre-theoretical deliberations on crime within spiritual existentialism

crime. We should also do research on crimes committed in the name of religion. The Roman Catholic inquisition and current jihad attacks are typical examples of such crimes. Such studies will enable us to develop theory on a vital part of human existence and open dimensions of crime causation hitherto not adequately covered in Criminology. Criminosophy should lead us into research that will help us in developing new theories on crime and the "supernatural". This is well summed up in the words of Hanegraaff (nd:9) when discussing western esotericism when he calls "..for the study of western esotericism not to restrict itself to empirico-historical description of narrowly-circumscribed currents and personalities, but also to develop interpretive theories pertaining to various dimensions of western esotericism in general".

\section{RECOMMENDATIONS}

We need to heed the wisdom of the father of phenomenology, Husserl, who declared that we should study things outside of the demand for veracity and validity. This means researchers must set aside the belief in what is true and real. This creates an opportunity for researchers to use phenomenology to study religion and worldviews that fall outside the positivistic paradigm. It is recommended that criminologists develop research studies that will involve more cross-disciplinary approaches, particularly with anthropology and religious studies. There is a dire need in our epistemology to engage the matters of metaphysics and particularly what is understood to be the spiritual world. 


\section{CONCLUSION}

Criminosophy or criminological philosophy should take cognisance of the fact that there are phenomena that are not easily explained with positivistic methodology. Yet phenomena in the metaphysical/transcendental domains impact on the lives and behaviour of people. Research should be undertaken that may challenge entrenched scientism and develop questions for research that can shed light on transcendental phenomena. Scientists are not comfortable when confronted by mysticism, metaphysical tendencies and religion. Whether it is western esoteric phenomena, African mysticism, occult practices or other supernatural phenomena, the challenge to criminologists is to engage these issues through specific epistemological practices that will allow us to get insight into how these phenomena are possibly associated/related with crime.

\section{LIST OF REFERENCES}

Beaulieu, T. (2011). Explaining Indigenous and Western therapeutic integration perspectives and experiences of Indigenous Elders. Available at: https://tspace.library.utoronto.ca/bitstream/1807/29471/1/Beaulieu_Teresa_R_201106_MA_thesis.pdf (accessed on: 11 October 2013).

Beiden, D. 2007. Science and Spirit: One reality, two kinds of knowledge. How can they work together to save the world? Available at: http://www.tikkun.org/nextgen/scienceand-spirit (accessed on 7 October 2015).

Bhaer, J. S. (nd) A Priori and A Posteriori. Available at: http://www.iep.utm.edu/apriori/ $\quad$ (accessed on 7 October 2015).

Braterman, P. 2014. The natural, the supernatural, and the nature of science. Available at: https://scientiasalon.wordpress.com/2014/07/14/the-natural-the-supernatural-andthe-nature-of-science/ (accessed on 8 October 2015).

Combs, W.W. 2000. 'How To Be Filled With The Holy Spirit', Christians Life. 2(4).Pp107-109. 
A paradigm shift in pre-theoretical deliberations on crime within spiritual existentialism

Connor, J. The Inklings. Available at:

http://www.worldews.com/post-it/the-inklings-by-johnconnor/ (accessed on 7 October 2015).

De Beer, J. 2012. 666Gangs: Devil worshipping gangs in South Africa. Available at: http://www.mobieg.co.za/articles/gangsterism/666-gangs/ (accessed on 9 October 2015).

Ellerby, J. 2006. Indigenous integrative phenomenology: Integrating indigenous African Epistimologies in Traditional healing research. PhD Thesis. Graduate Theological Foundation.

Encyclopaedia Britannica, 2015. Logical positivism. http://global.britannica.com/topic/logical-positivism. Available at: http://global.britannica.com/topic/logical-positivism (accessed on 21 September 2015).

Erasmus, N. 2015 Demonic game irks parents. Observer, 8 October 2015. p.6

Family Safe Media Statistics. 2011. Internet Pornography: Facts and figures. Alabama Policy Institute. Available at: http://www.familysafemedia.com/pornography_statistics.html (accessed on 25 May 2011).

Fenteleve, M. 2010. Strong Muti \& Harm Ye None: two worlds apart. Available at: http://www.penton.co.za/strong-muti-harm-yenone-two-worlds-apart/ Accessed on 6 May 2016.

Fields, R 1991. The Code of the Warrior: In History, Myth, and Everyday Life. Harper Collins

Fouche, L 2012 Occult crimes on the rise in schools. Available at: http://www.bloemfonteincourant.co.za/article/286/Occultcrimes-on-the-rise-in-schools (accessed on 9 October 2015).

Groff, I. \& Smoker, P. 1996. Spirituality, religion, culture, and peace: Exploring the foundations for inner-outer peace in the twenty-first century. Available at: http://www.gmu.edu/programs/icar/ijps/vol1_1/smoker.html Accessed on 4 May 2016.

Hall, S. 2005 Christian? or Secular Humanist? Available at: http://www.aboundingjoy.com/humanism_chart.htm (accessed on 7 October 2015.

Hallett, A. 1999. Christian Criminology: Religious Values and Criminal 
Justice Policy. Available at: http://archives.wineskins.org/article/christian-criminology-religious-values-and-criminaljustice-policy-sep-oct-1999/ (accessed on 13 October 2015).

Hanegraaff, W.J. (nd.) Some Remarks on the Study of Western Esotericism. Available at: http://www.esoteric.msu.edu/Hanegraaff.html (accessed on 13 October 2015).

Himes, H. \& Schulenberg, J.2013. Theoretical Reflections: Theory and Philosophy Should Always Inform Practice. Available at: https://www.nacada.ksu.edu/Resources/Academic-Advising-Today/View-Articles/Theoretical-Reflections-Theoryand-Philosophy-Should-Always-Inform-Practice.aspx (accessed on 13 October 2015).

Izibili, M.K. 2009. African Traditional Approach to the Problems of Evil in the World. Available at: http://www.krepublishers.com/02-Journals/T\%20\&\%20T/T\%20\&\%20T-07-0-000-09Web/T\%20\&\%20T-07-1-000-09-Abst-PDF/T\&T-07-1011-09-156-Izibili-M-A/T\&T-07-1-011-09-156-Izibili-MA-Tt.pdf (accessed on 8 October 2015).

Kennedy, W.H. 2006. Satanic Crime: A Threat in the New Millennium. Available at: http://www.whale.to/c/sataniccrime.pdf (accessed on 17 September 2015).

Krishnananda, S. 2015. The Path to Freedom: Mastering the Art of Total Perception http://www.swami-krishnananda.org/freedom/freedom_04.html (accessed on 3 July 2015).

Lamprecht A. 2014. Occult related practices on the rise - SAPS. Available at: http://www.sanews.gov.za/south-africa/occultrelated-practices-rise-saps (accessed on 9 October 2015.

Landauer, J. \& Rowlands, J. 2001. Introduction to the Five Branches of Philosophy. Available at: http://www.importanceofphilosophy.com/FiveBranchesMain.html (Accessed on 5 October 2015).

Maromo, J. 2013. Marikana commission: Strikers used muti, believed they were invincibleAvailable at: http://mg.co.za/article/201311-26-marikana-commission-strikers-used-muti-believed- 
A paradigm shift in pre-theoretical deliberations on crime within spiritual existentialism

they-were-invincible Accessed on 6 May 2016.

Mastin, L. 2008. The basics of Philosophy. Available at: http://www.philosophybasics.com/branch_logical_positivism.html (accessed on 7 October 2015.

Momoh, C.S. (Ed.) 1989. The Substance of African Philosophy. Auchi: African Philosophical Projects.

Okawa, R. 2015. The Truth about Spiritual Possession. Available at: http://info.happy-science.org/2015/127/ (accessed on 5 October 2015).

Ovens, M. \& Prinsloo, J. 2010. An exploration of a traditional African paradigm in a postmodern world with specific reference o criminology. Acta Criminologica. Crimsa 2009 Conference Special edition No. 2/2010. Pp. 1-10.

Perlmutter, D. 2013. The Forensics of Sacrifice: A Symbolic Analysis of Ritualistic Crime. Available at: http://www.anthropoetics.ucla.edu/ap0902/sacrifice.htm (accessed on 5 October 2015).

Pieterse, C. \& and Umraw, A. 2015. Is it a 'demonic' game? Available at: http://www.news24.com/SouthAfrica/News/Is-it-a-demonic-game-20150904 (Accessed on 13 October 2015).

Raddon, A. 2010. Early Stage Research Training: Epistemology \& Ontology in Social Science Research. Available at: https://www2.le.ac.uk/colleges/ssah/documents/researchtraining-presentations/EpistFeb10.pdf (accessed on 7 October 2015).

Roelofse, CJ. 2014. Ritual and muti murders amongst the vha-Venda people of South Africa: An ethno-criminological assessment of the phenomenon and development of a new typology. Acta Criminologica (Special edition: Research and application in Criminology \& Criminal Justice/1/2014

SAPA, 2014. Muti works "mr. X" tells Farlam commission. (1July2014) Available at: http://www.timeslive.co.za/local/2014/07/01/muti-works-mr-X-tells-marikana-commission Accessed on 6 May 2016

Smith, J.C. \& Welsh, A. 2013. Creationism Case: John Freshwater Lawyers Spar With Mount Vernon School Board In Ohio Bible Case. Available at: http://www.huffingtonpost.com/2013/02/27/creationism-john-freshwater_n_2773977.html (accessed on 5 October 2015). 
Spencer, R. 2013. UK: Muslim abuser who "didn't know" that sex with a 13-year-old girl was illegal is spared jail. Available at: http://www.jihadwatch.org/2013/01/uk-muslim -abuserwho-didnt-know-that-sex-with-a-13-year-old-girl-was-illegal-isspared-jail (Accessed on 7 October 2015).

Swindal, J. Faith and reason. Available at: http://www.iep.utm.edu/faith-re/ (Accessed on 27 February 2017).

Valentine, J. 2011. Black Magic: African-American Ambivalence to Superstition \& the Supernatural. Available at: http://www.clutchmagonline.com/2011/06/black-magicafrican-american-ambivalence-to-superstition-the-supernatural/ (accessed on 13 October 2015).

Van Binsbergen. W.M.J. 2015 African Spirituality: An Approach from Intercultural Philosophy. Available at: http://them.polylog.org/4/fbw-en.htm (accessed on 7 October 2015).

Vlach, M. 20025 Branches of philosophy. Available at: http://theologicalstudies.org/resource-library/philosophy-dictionary/85-5branches-of-philosophy Accessed on 7 October 2015

Warren, M. E. (1989). What is a political theory/philosophy? PS: Political Science and Politics, 22(3), 606-612.

Younkins. E. 2000 Why the World is the Way It Is: Cultural Relativism and It's Descendents. Available at: http://www.quebecoislibre.org/younkins26.html (accessed on 7 October 2015).

Zaimov, S. 2013. Muslim Claims He Didn't Know Rape Was Illegal; Spared Prison by UK Court. Available at: http://m.christianpost.com/news/muslim-claims-he-didnt-know-rapewas-illegal-spared-prison-by-uk-court-89106/ (accessed on 20 September 2015).

\section{Acts}

National Environmental Management: Biodiversity Act, Act 10 of 2004 Witchcraft Suppression Act 3 of 1957

\section{Case Law}

Preliminary Inquiry: No: PLI 137/2014. Protea court 